8. Kyzylova, V. (2016). Literatura dlya ditey ta yunatstva $\mathrm{v}$ konteksti reformuvannya zmistu literaturnoyi osvity $\mathrm{v}$ Ukrayini [Literature for children and youth in the context of reforming the content of literary education in Ukraine]. Bulletin of the Center for the Study of Literature for Children and Youth "Literature. Children. Time". Vol. VI: Proceedings of the 5th All-Ukrainian Scientific and Practical Conference "Ukrainian Literature for and About Children: Historical
Achievements and Development Trends"(October 11,2016). Starobilsk: Luhansk National University Publishing House. Taras Shevchenko. pp. 76-82. [in Ukrainian].

9. Chystyakova, O. S. (2016). Linhvostylistychnyy analiz khudozhnoho tekstu [Linguistic and stylistic analysis of an artistic text]. Scientific notes of the National University “Ostroh Academy”. Philological series. Issue 60. pp. 297-299. [in Ukrainian]

Стаття надійшла до редакції 14.07.2021

УДК 929:378:37.091.12.011.3-051(045)

DOI:

Ірина Розман, кандидат педагогічних наук, доцент кафедри англійської філології та методики викладання іноземних мов Мукачівського державного університету

\title{
ВИКОРИСТАННЯ ЗДОБУТКІВ ПЕДАГОГІЧНОЇ БІОГРАФІСТИКИ В ПРОФЕСІЙНІЙ ПІДГОТОВЦІ МАЙБУТНІХ ПЕДАГОГІВ
}

Обтрунтована потреба у необхідності використання здобутків педагогічної біографістики для підготовки студентів закладів освіти педагогічного спрямування, ше дає змогу вдосконалити набутии теоретико-практичний матеріал щуодо життєдіяльності відомих і маловідомих педагогів. Зосереджено увагу на практичних рекомендачіях вивчення біографії педагогів. Запропонована конкретна тематика для практичної роботи зі здобувачами вищяої освіти.

Закиентована увага на те, щуо вивчаючи різновидові джерельні матеріали у професійній підготовці майбутніх педагогів, зокрема у викладанні дисииплін гуманітарного і психолого-педагогічного ичклів “Педагогіка”, “Історія педагогіки”, “Методологія наукового дослідження”, “Теорія іметодика виховання” та інші, в організаиї науково-дослідницької роботи здобувачам освіти важливо дослідити педагогічну біографістику у системі сучасної науки та освіти.

Ключові слова: педагогічна біографістика; здобутки; практичне використання; джерелознавчий компонент.

Jim. 6.

Iryna Rozman, Ph.D.(Pedagogy), Associate Professor of the English Philology and Methods of Teaching Foreign Languages Department Mukachevo State University

\section{USE OF ACHIEVEMENTS OF PEDAGOGICAL BIOGRAPHY IN PROFESSIONAL TRAINING OF FUTURE TEACHERS}

The development and formation of the individual, providing comprehensive conditions for self-development is one of the main tasks of the field of teacher education at the stage of integration into the European educational space. Higher education, on the path of rearrangement, involves training future teachers to use the already acquired theoretical and methodological material and to further improve practical skills.

The purpose of the article is to substantiate the need to use the achievements of pedagogical biographical studies in the professional training of future teachers. The article substantiates the need to use the achievements of pedagogical biographical studies for training students of educational institutions of pedagogical direction, which makes it possible to improve the acquired theoretical and practical material on the life of well-known and littleknown teachers. Attention is focused on practical recommendations for studying the biography of teachers. Specific topics for practical work with applicants for higher education are proposed. Studying various source materials in the professional training of future teachers, in particular in teaching the disciplines of humanitarian and psychological-pedagogical cycles "Pedagogy", "History of pedagogy", "Methodology of scientific research", "Theory and methodology of education" and others, in the organization of research work, it is important for applicants to study pedagogical biographical studies in the system of modern science and education, to find out the theoretical concepts of biographical teachings, to use general scientific, historical-pedagogical and interdisciplinary methods of pedagogical biographical studies, general information about the sources of research of pedagogical personalities, documentary sources as an aspect of pedagogical biographical studies, get acquainted with the features of studying personalities by Ukrainian Soviet pedagogical science, explore the personalized direction of 


\section{ВИКОРИСТАННЯ ЗДОБУТКІВ ПЕДАГОГІЧНОӤ БІОГРАФІСТИКИ В ПРОФЕСИЙНІЙПІГОТОВЦІМАЙБУТНІХПЕДАГОГІВ}

pedagogical comparativistics: integrative approach, accumulation and means of popularizing the achievements of famous teachers of Ukraine.

Keywords: pedagogical biographical studies; achievements; practical use; source studies component.

П остановка проблеми. Розвиток та становлення особистості, забезпечення всебічних умов для саморозвитку - одне 3 головних завдань галузі педагогічної освіти на етапі інтеграції в європейський освітній простір. Вища освіта на шляху перебудови передбачає підготовку майбутніх педагогів для вміння використовувати вже набутий теоретикометодологічний матеріал та для подальшого вдосконалення практичних навичок.

Аналіз наукових досліджень. Теоретичну основу дослідження складає доробок українських вчених з теорії і практики навчання і виховання (І.Бех, О. Вишневський, Г. Ващенко, В. Гінецинський, А. Макаренко, С. Миропольський, С. Русова, В. Сухомлинський), з теорії і практики джерелознавства, бібліографії, історіографії у галузях історичної науки (О. Богдашина, Я. Калакура, I. Ковальченко, I. Корнсйчик, Л. Мазур, С. Павленко, Г. Швецова-Водка, О. Яценко та ін.) та історико-педагогічної науки (Є. Александров, Н. Вараскіна, Л. Голубнича, Н. Гупан, Е. Днєпров, Н.Мацібора,І.Стражнікова, О.Петренко,Н.Побірченко, Д. Раскін, О. Сухомлинська та ін.).

Мета статті полягас в обгрунтуванні потреби використання здобутків педагогічної біографістики в професійній підготовці майбутніх педагогів.

Виклад основного матеріалу. Виміри національної педагогічної біографістики в ракурсі історичних змін та перетворень державнополітичної і соціально-економічної системи займають вагоме місце для інтеграції України в світовий культурно-історичний простір, що $\epsilon$ стимулом всебічної модернізації освіти. Всі зміни сьогодення так чи так пов'язані 3 історичними змінами у суспільстві.

Згідно із Законом України “Про освіту”, метою освіти є "підготовка конкурентоспроможного людського капіталу для високотехнологічного та інноваційного розвитку країни, самореалізації особистості, забезпечення потреб суспільства, ринку праці та держави у кваліфікованих фахівцях" [2]. Сучасні вимоги до підготовки студентів педагогічних ЗВО до роботи у закладах освіти та формування практичних життевих навичок, активної участі у виробничій діяльності, набуває особливого значення формування у студентів гнучких навичок. Це надбання приходить тільки з умінням виокремлювати головне і необхідне для результативної роботи. Нагромаджений значний досвід у проведенні біографічних досліджень, може бути корисним для розробки методологічних засад, науково-дослідницького інструментарію педагогічної біографістики. Знання способів і форм використання набутої інформації - це швидкий і безпомилковий розв 'язок поставлених завдань.

Педагогічна біографістика, має можливість комплексно досліджувати та обгрунтовувати біографію особистості (відомості про час і місце народження, походження, родинне середовище, освіту, риси характеру, приватне життя тощо); професійну біографію персоналії (праця за фахом, наукова позиція, контакти, зв'язки); біобібліографію праць (аналіз творчого доробку, історія його створення, техніки і методології дослідження, поняттєвий апарат) та висвітлювати ситуативну біографію (визначні і виняткові події, факти) і “біографію навколишнього середовища" [5, 51].

Біографістика як напрям і складник педагогічної науки може досліджуватися з різних методологічних позицій, однак завжди через призму міждисциплінарного підходу. Це, з одного боку, актуалізується зміною теоретичних парадигм, що орієнтують на інтерпретативні науково-дослідні стратегії та зосередження уваги на суб'єктивно-особистісних значеннях і смислах. 3 іншого боку, міждисциплінарність детермінується сутністю феномену життєпису, що як окремий жанр розвивається на перетині історії, літератури, філософії, психології, соціології, фізіології, мовознавства, інших галузей соціогуманітарних і біологічних наук. У такому ракурсі варто пригадати зроблений на основі аналізу досвіду біографістики умовивід відомого англоамериканського вченого А. Дж. Тейлора, згідно 3 яким найкращі зразки життєписів стали результатом поєднання досягнень кількох галузей знань, бо саме такий синтез дозволяє з більшою ймовірністю, точністю відтворити історію життя героя біографічної оповіді $[5,25]$.

Дослідження спадщини відомих та маловідомих педагогів, науковців, учителівпрактиків, які у своїй роботі доводили значущість теоретико-практичних надбань; подолання байдужості до проблем освіти і виховання; розкриття аспектів історії педагогіки через вивчення її у динаміці на різних етапах розвитку суспільства; вивчення національного досвіду 3 питань теорії і практики навчання та виховання, яке завжди сприяе вдосконаленню сучасних освітніх технологій; систематизація та аналіз вченого, фахівця, педагога в суспільно- 


\section{ВИКОРИСТАННЯ ЗДОБУТКІВ ПЕДАГОГІЧНОЇ БІОГРАФІСТИКИ}

В ПРОФЕСІЙНІЙ ПДГОТОВЦІ МАЙБУТНІХПЕДАГОГІВ

історичному, теоретичному, методичному, методологічному, загальнокультурному напрямі роботи; дослідження не тільки відмінного володіння педагогічними та психологопедагогічними знаннями щодо особистості загалом, a i практичного використання педагогічних засобів та методів впливу на формування характеру людини, - все $\epsilon$ завданнями для використання здобутків педагогічної біографістики в професійній підготовці майбутніх педагогів.

Вивчаючи різновидові джерельні матеріали у професійній підготовці майбутніх педагогів, зокрема у викладанні дисциплін гуманітарного і психолого-педагогічного циклів "Педагогіка", "Історія педагогіки", “Методологія наукового дослідження”, “Теорія і методика виховання” та інші, в організації науково-дослідницької роботи здобувачам освіти важливо дослідити педагогічну біографістику в системі сучасної науки та освіти, з'ясувати теоретичні поняття біографічних учень, використовувати загальнонаукові, історикопедагогічні та міждисциплінарні методи педагогічної біографістики, загальні відомості про джерела дослідження педагогічних персоналій, документальні джерела як аспект педагогічної біографістики, ознайомитись 3 особливостями вивчення персоналій українською радянською педагогічною наукою, дослідити персоніфікований напрям педагогічної компаративістики: інтегративний підхід, акумулювання та засоби популяризації надбань відомих педагогів України [4, 24-25].

Запропоновані матеріали сприятимуть вивченню теоретичних напрацювань, практичних здобутків, автобіографічних відомостей, джерелознавчого матеріалу, особистих та історичних архівних матеріалів відомих і маловідомих педагогів, вчених, фахівців з історії педагогіки.

У зв'язку з тим, що предметом системного цілісного аналізу стала проблема формування i розвитку педагогічної біографістики в Україні у другій половині XX - на початку XXI ст., є всі підстави стверджувати, що виникла необхідність не тільки теоретичного, a i практичного обгрунтування доцільності використання здобутків педагогічної біографістики в професійній підготовці майбутніх педагогів.

На аудиторних заняттях студенти для відпрацювання практичних навичок застосовують орієнтовний план дій, який міститься у методичних розробках для самостійної та індивідуальної роботи студентів, навчальних посібниках.

Джерельна база, історіографія, тенденції формування і розвитку педагогічної біографістики в Україні в другій половині XX - на початку XXI ст. та визначенні можливості використання цього наукового досвіду в подальшому розвитку студій про педагогічні персоналії і вдосконаленні сучасного освітнього процесу, - надзвичайно важливі у сучасному світі, де відбувається біографічний бум $[5,7]$.

Для якісного впровадження здобутків педагогічної освіти в професійній підготовці майбутніх фахівців, необхідно визначити теоретико-методологічні засади педагогічної біографістики в контексті сучасного наукового дискурсу, з'ясувати передумови, генезу та основні етапи і тенденції становлення й розвитку педагогічної біографістики в Україні. Особливу увагу необхідно звернути на структурнофункційний аналіз джерел педагогічної біографістики, визначити їхній інформаційний потенціал і особливості, показати процес формування і рівень розвитку педагогічної бібліографії і біобібліографії в Україні [6].

Педагогічна біографістика має розвиватися на міждисциплінарній основі, що передбачає тісні взаємозв'язки з різними галузями педагогічної науки та гуманітарних знань. Вони мають будуватися на засадах “відносного паритету", коли, з одного боку, біографістика запозичує та оперує науковим інструментарієм загальної педагогіки, історії педагогіки та соціальної, вікової, професійної, порівняльної, інших напрямів і галузей педагогіки [3, 64]. 3 іншого, вона пропонує свої здобутки про життя і творчість педагогічних персоналій, корисні для їхніх науководослідницьких і практично-технологічних потреб гумінітаристики.

На відміну від представників інших галузей знань, які констатують здобутки попередників і за потреби спираються на них у своїх дослідженнях, майбутній фахівець, учений-педагог працює за формулою: “Із минулого через сучасність - у майбутнє”. Тобто він має з'ясувати і пояснити, як певна ідея, теорія, концепція сформувалася у свідомості досліджуваної персоналії; у чому полягає їхня оригінальність і значущість; як вони вплинули на подальший розвиток педагогічної думки; яке місце посіли в історії освіти тощо [1, 162-167].

Зі згаданими вище тісно пов'язані принципи творчої оригінальності й самодостатності; дотримання норм наукової етики; максимального заглиблення у наукову проблему; практичної орієнтованості й ефективності результатів дослідження. Їхня реалізація передбачає: a) поєднання поваги до доробку сучасних науковців, учених, що працювали за різних історичних періодів, зарубіжних колег із його 


\section{ВИКОРИСТАННЯ ЗДОБУТКІВ ПЕДАГОГІЧНОӤ БІОГРАФІСТИКИ}

В ПРОФЕСИЙНІЙПДГОТОВЦІ МАЙБУТНІХПЕДАГОГІВ

творчо-конструктивним прочитанням і принципово-критичним аналізом; б) виявлення наукової сміливості, самостійності, обачливості в судженнях і висновках, творчого ставлення до усталених парадигм і поглядів, що стимулює продукування власних умовиводів, самовіддачу i самореалізацію в процесі наукової роботи; в) використання, окрім традиційних, інноваційних і неапробованих методологічних стратегій, що дає змогу виходити на нові рівні осмислення біографії; г) цілеспрямоване комплексне занурення у проблему, що передбачає з'ясування внутрішніх взаємозв'язків і закономірностей розвитку життєвого і творчого шляху персоналії через вивчення і з'ясування в руслі наукового дискурсу спершу “відомого”, відтак “маловідомого і прихованого”, “значущого, вартісного, помилкового”; г) системне (тобто не лише в прикінцевих висновках) визначення та обгрунтування теоретичної і практичної значущості положень і результатів дослідження для розвитку педагогічної науки, удосконалення освітнього процесу, реформування системи освіти тощо [5, 384].

Необхідно зауважити, що аналіз педагогічної персоналії як творчої особистості становить ідея, згідно 3 якою розвиток особистості супроводжується і проявляється у своєрідній динаміці різних людських типів та інтегрується в єдності біологічних і соціально-типових тенденцій. Майбутній педагог має розуміти, що між типами вищої нервової діяльності, з одного боку, та характером, творчим потенціалом особистості, 3 іншого, існує безсумнівний і виразний зв'язок, який потрібно виявити та пояснити, зокрема крізь призму його впливу на зміст і результат теоретичних пошуків особи, яку досліджує, професійно-освітніх, науково-організаційних, інших виявів ії̈ суспільної активності [5, 394].

Висновки та перспективи подальших досліджень. Отже, з огляду на необхідність використання здобутків педагогічної біографістики в професійній підготовці майбутніх педагогів, доволі продуктивним науково-методологічним інструментом для дослідження педагогічних персоналій є їі практична спрямованість. Вона містить сукупність цінних ідей, теорій, підходів, принципів вивчення особистості, зокрема педагога як історичної персоналії, у її цілісних структурних типологічних і динамічних характеристиках.

Готуючи майбутніх педагогів, ми спрямовуємо здобувачів вищої освіти бути персонологом, щоб уміти глибше виявляти, аналізувати, розуміти складний внутрішній світ досліджуваної персоналії. Це дає важливий ключ до вивчення ії життєдіяльності як складного, багатовимірного феномену. Як ефективний компонент результативності актуалізуємо увагу на творчому підході щодо дослідження життедіяльності педагогів.

\section{ЛІТЕРАТУРА}

1. Голубнича Л. О. Класифікація джерел педагогічних персоналій. Педагогічний дискурс: зб. наук. праць / гол. ред. І. М. Шоробура. Хмельницький: ХГПА, 2013. Вип. 15. С. 162-167.

2. Закон України "Про освіту". URL: https:// zakon.rada.gov.ua > laws> show. 2017.

3. Пономаренко Л. Аналіз системи бібліографічних видань України з питань педагогіки і психології (2005-2009 рр.). Наук. пр. Нац. б-ки України ім. В. І. Вернадського. Київ, 2011. Вип. 31. С. 63-69.

4. Розман I. І.Педагогічна біографістика: навчальний посібник. Ужтород: РІК-У, 2020.188 с.

5. Розман I. I. Українська педагогічна біографістика (друга половина XX - початок XXI століття) : монографія. Ужгород : РІК-У, 2020. 618 c.

6. Сухомлинська О. Концептуальні засади розвитку історико-педагогічної науки в Україні. Шлях освіти. 1999. № 1. С. 41-45.

\section{REFERENCES}

1. Holubnycha, L. O. (2013). Klasyfikatsiia dzherel pedahohichnykh personalij [Classification of sources of pedagogical personnel]. Pedagogical discourse: coll. of Science. works. (Ed.). I.M. Shorobura. Khmelnytskyi, Vol. 15.pp. 162-167. [in Ukrainian].

2. Zakon Ukrainy "Pro osvitu" (2017). [The law of Ukraine "On Education”]. Available at: https:// zakon.rada.gov.ua > laws> show [in Ukrainian]

3. Ponomarenko, L. (2011). Analiz systemy bibliohrafichnykh vydan Ukrayiny z pytan pedahohiky i psykholohiyi (2005-2009 rr.) [Analysis of the system of bibliographic publications of Ukraine on pedagogy and psychology (2005-2009)]. Scientific works of Nat. Library of Ukraine named after V.I. Vernadsky, Vol. 31.pp. 63-75. [in Ukrainian].

4. Rozman, I. I. (2020). Pedahohichna biohrafistyka: navchalnyi posibnyk [Pedagogical biology: a textbook]. Uzhhorod, 188 p. [in Ukrainian].

5. Rozman, I. I. (2020). Ukrayinska pedahohichna biohrafistyka (druha polovyna XX-pochatok XXI stolittya) [Ukrainian pedagogical biography (second half of the XX-beginning of the XXI century)]. Uzhhorod, 618 p. [in Ukrainian].

6. Sukhomlynska, O. (1999). Kontseptualni zasady rozvytku istoryko-pedahohichnoi nauky v Ukraini [Conceptual Fundamentals of the Development of Historical and Pedagogical Science in Ukraine]. The path of education. Vol. 1. pp. 41-45. [in Ukrainian].

Стаття надійшла до редакції 14.07.2021 